\title{
Carbonation-induced corrosion minimization in steel reinforced concrete structures
}

\author{
G. Abaho ${ }^{1}$, M. R. Pranesh ${ }^{1}$, G. Senthil Kumaran ${ }^{2, *}$ \\ ${ }^{1}$ Department of Civil Engineering, Jain University, Bangalore, India \\ ${ }^{2}$ Department of Civil, Environmental and Geomatics Engineering, University of Rwanda, Kigali, Rwanda
}

\section{A R T I C L E IN F O}

\section{Article history:}

Received 17 September 2016

Received in revised form

12 December 2016

Accepted 20 March 2017

\section{Keywords:}

Reinforced concrete structures

Carbonation-induced corrosion

Carbonation coefficient

\begin{abstract}
A B S T R A C T
The aim of the work was to find out the corrosion condition, cause and remedial solution for reinforced concrete structures located at non coastal regions. Concrete cover thickness ranged from $12 \mathrm{~cm}$ to $50 \mathrm{~cm}$. Rebound hammer strength ranged from $(12-28) \mathrm{N} / \mathrm{mm} 2$. The $\mathrm{pH}$ ranged between 8 and 12 but $85 \%$ of $\mathrm{pH}$ was below 10 . Results show that for corrosion conditions more than $80 \%$ quai-situation value lay between $(-0.420$ and 0.380 ) VCSE which indicates high probability of corrosion of reinforcement. Real structures surveyed also indicated that they were devoid of maintenance schedules. Irrespective of structural member, survey data on analysis indicate an average carbonation coefficient $(\mathrm{K})$ of $3.83 \mathrm{~mm} /$ year $^{0.5}$ in concrete structure exposed to Bangalore atmosphere. Hence, the study indicates that regular maintenance schedules for reinforced concrete structures are essential with preventive approach. Carbonation induced corrosion was accelerated by $490 \mathrm{ppm}$ concentration of Carbon dioxide in the surrounding environment of the surveyed structures. It was facilitated by the deficiency in construction practices like inadequate concrete cover, high w/c ratio hence poor quality of concrete in general.
\end{abstract}

(C) 2017 The Authors. Published by IASE. This is an open access article under the CC BY-NC-ND license (http://creativecommons.org/licenses/by-nc-nd/4.0/).

\section{Introduction}

The infrastructure development in the country is essential for its improvement in social-economic status. The sustainable development however, would be limited by the reduced designed life of the reinforced structures due to corrosion effect in structures. Carbonation-induced corrosion of steel in reinforced concrete structures is common in noncoastal regions.

The recent findings from real structures, has presented that more than $80 \%$ of the surveyed structures in Bangalore suffered carbonation induced corrosion (Abaho et al., 2015). Carbonationinduced corrosion of steel in reinforced concrete structures has been overlooked.

Bangalore city is among the fast-developing cities in India with industrial and economic activities at fore front. Since 1973-2009, Bangalore city has increasingly experienced growth of $632 \%$ and average atmospheric temperature with an increase

\footnotetext{
* Corresponding Author.

Email Address: kumarangs@yahoo.com (G. S. Kumaran) https://doi.org/10.21833/ijaas.2017.06.010

2313-626X/C) 2017 The Authors. Published by IASE.

This is an open access article under the CC BY-NC-ND license

(http://creativecommons.org/licenses/by-nc-nd/4.0/)
}

of 2 to $2.5^{\circ} \mathrm{C}$ in the last decade (Ramachandra and Kumar, 2010).

The city is located at the elevation within the plateau region of the southern India peninsula and equidistant $(\sim 300 \mathrm{~km})$ from both east and west coast (Sudhira et al., 2007). Arabian Sea is in the west and Bay of Bengal is in the east. Carbon dioxide $\left(\mathrm{CO}_{2}\right)$ is reported to turn to $490 \mathrm{ppm}$ in morning and $390 \mathrm{ppm}$ in evening in Bangalore due to development activities including cement production and electricity production, transportation in general and other fossil fuel burning actives (Guha and Ghosh 2015). Carbon dioxide concentration in atmosphere in USA was 316 ppm in 1959 and 390ppm in 2011 (Gajanan, 2012). This indicates that $\mathrm{CO}_{2}$ level in atmosphere environment in Bangalore is very much high. With durability definition, concrete is expected to be resistant to weather and withstand aggressive environment providing the required protection against reinforcement corrosion (Schiessl, 1998). The durability of structures is affected if the structures cannot stand the available environment and start showing defects during their service life before the design service life is reached. Although a durable structure is expected to serve without deterioration to the extent that major repair is required before expiry of its design life, it must not 
be presumed that durability is a subjected to good maintenance. Even for a structure that has been designed and constructed to a high durability standard, regular inspection and routine maintenance to restore the fitness for purpose of the structure are needed.

Carbonation and chloride ion attack in concrete are the most common causes of steel corrosion in reinforced concrete (Ahmad, 2006; Fu and Chung, 1997; Saetta et al., 1993; Ho and Lewis, 1987; Neville, 2004; Broomfield, 1997). It is expected that carbonation attack would be different since it differs from one place to another due to difference in pollution. It is normally $0.03 \%$ of gas concentration in atmosphere but higher than this in cities due to increased pollution prevailing in such environment. Carbonation rate and carbonation depth in a concrete structure mostly depends on carbon dioxide concentration in surrounding environment of relative humidity, density, quality of concrete, time and conditions of exposure.

In most cases, steel reinforcements are exposed to the atmosphere during transportation and storage in the building sites for a long period before their installation in the concrete structures. In such a case, simple uniform brownish scales (rust) are formed on the surface of reinforcement, these have no effect on their mechanical performance and they may increase the bond strength of the reinforcement to concrete. However, the thickness of rust should not more than $150 \mu \mathrm{m}$ otherwise the bond strength may be affected (Fu and Chung, 1997). Corrosion of steel may lead to the reinforcement lose its useful engineering properties like ductility which lead to the sudden breakdown of the reinforced structure. A period of 17 months of exposure to the atmosphere may cause a significant corrosion that can affect the yield and ultimate tensile strength of the steel bars (Maslehuddin et al., 1996). Corrosion of steel in structures for long time leads to loss of bond between concrete and steel reinforcement (Maslehuddin et al., 1996). This implies that precaution measures should be taken in transportation, storage and handling of rebar to protect severe corrosion. It has significant implication on the durability of the structure in as regards corrosion of steel in concrete is concerned. This paper highlights both air pollution (CO2) up to $490 \mathrm{ppm}$ and increase temperature by $+2.5^{\circ} \mathrm{C}$ in last two decades to be among the major causes of corrosion of steel in Reinforced Concrete (RC) structures at Bangalore city in India. This is also favored by the average relative humidity of $65 \%$ that prevails in Bangalore city.

The findings of survey conducted on fourteen structures in this city, has indicated carbonation depth in reinforced concrete penetrated up to the level of steel surface in six years (Abaho et al., 2015). Reinforcements are prevented from corrosion by the formation of a passive oxide film in the high $\mathrm{pH}$ environment of concrete. However, due to the ingress of species which include but not limited to moisture, oxygen, sulphates, chlorides and especially
$\mathrm{CO}_{2}$ into the concrete, the $\mathrm{pH}$ is reduced below 9 then the reinforcements are not passivated. When carbon dioxide reacts with moisture carbonic acid is produced and then reacts with lime to form calcium carbonate is termed as carbonation (Ho and Lewis, 1987). In the presence of oxygen and water; corrosion of steel will be initiated. Reinforced concrete structures perform well as long as the alkaline environment is intact (Neville, 1995).

Eq. 1 shows the precipitation of calcium carbonate:

$\mathrm{Ca}(\mathrm{OH})_{2}+\mathrm{CO}_{2} \quad \mathrm{CaCO}_{3}+\mathrm{H}_{2} \mathrm{O}$
Step $1 \mathrm{H}_{2} \mathrm{O}+\mathrm{CO}_{2}=\mathrm{HO}_{-3}+\mathrm{H}^{+}$
$\mathrm{HCO}_{-3}=\mathrm{CO}_{3}+\mathrm{H}^{+}$
Step 2
$\mathrm{Ca}(\mathrm{OH})_{2}+2 \mathrm{H}^{+}+\mathrm{CO}_{3}^{2}=\mathrm{CaCO}_{3}+2 \mathrm{H}_{2} \mathrm{O}$

The process of $\mathrm{CO}_{2}$ diffusion can then be modelled based on Fick's first law. Based on the diffusion law, the carbonation rate is proportional to the square root of the time of exposure to the $\mathrm{CO}_{2}$ (Broomfield, 1997). Under steady conditions, the depth of carbonation increases in proportion to the square root of time, as depicted by the following Eq. 4:

$d_{c}=K t^{t / 2}$

In Eq. $4, \mathrm{~d}_{\mathrm{c}}=$ depth of carbonation, $\mathrm{K}=$ carbonation coefficient and $\mathrm{t}=$ time of exposure to $\mathrm{CO}_{2}$ in years. Good concrete has a K- value between 0.25 and $1 \mathrm{~mm} /$ year $^{0.5}$ (Broomfield, 1997; Bentur et al., 1997).

The experimental data showed that carbonation coefficient in good concrete has values around 1-1.5 $\mathrm{mm} /$ year $^{0.5}$, but can increase to 7.0 and 8.0 (mm/year $\left.{ }^{0.5}\right)$ for medium concrete and environmental situation even it can be more 9 in poor concrete with high porosity and cement content of $250 \mathrm{~kg} / \mathrm{m}^{3}$ and below (Neville, 1995). Relative humidity between $50-70 \%$ accelerates the rate of carbonation, but at some lower level than $30 \%$ it may not be enough to facilitate carbonation process and higher than that water limits $\mathrm{CO}_{2}$ diffusion. It is reported that two folds' higher corrosion rate could be reached by $10^{\circ} \mathrm{C}$ increase in temperature and also confirms the same finding by Berke and Hick (1994). Also it was found that carbonated specimens had a logarithmic rise in corrosion rate with temperature from $-20^{\circ} \mathrm{C}$ to around $30^{\circ} \mathrm{C}$ (Tuutti, 1982). Accelerated tests carried out in the laboratory to compare the resistance to carbonation in different types of concrete show that, indicatively, one week of exposure to an atmosphere containing $4 \% \quad \mathrm{CO}_{2}$ will cause the same penetration of carbonation as a year of exposure to a normal atmosphere (AlKadhimi et al., 1996).

It was found that $100 \%$ of $\mathrm{CO}_{2}$ under increased pressure produce the same microstructure as natural carbonation (Al-Kadhimi et al., 1996). Some codes have estimated carbonation induced corrosion initiation as shown in Table 1. 
Table 1: Time to initiate corrosion

\begin{tabular}{cccc}
\hline $\begin{array}{c}\text { Structure Element } \\
\text { type }\end{array}$ & $\begin{array}{c}\text { Clear cover }(\mathrm{mm}) \\
\text { (ACI-138-11) }\end{array}$ & $\begin{array}{c}\text { Average Carbonation } \\
\text { Coefficient }\end{array}$ & $\begin{array}{c}\text { Time to initiate corrosion } \\
\text { Corrosion per year }\end{array}$ \\
\hline Slab & 19 & & 18 \\
Beam & 37.5 & 3.83 & 96 \\
Column & 37.5 & & 96 \\
\hline
\end{tabular}

The corrosion of reinforcement behavior and corrosion rate will depend on the time of exposure, concrete clear cover and carbonation coefficient of the structure in question as shown in Table 1. "Building Code Requirements for Structural Concrete" American Concrete Institute, Farmington Hills, USA. For specified concrete cover as per ACI 318-11 (ACI, 1992) the time to initiate corrosion of different structural elements are calculated and summarized in Table 1. Here, carbonation coefficient is assumed to be $3.83 \mathrm{~mm} /$ year $^{0.5}$. It is assumed that, after 18years of exposure, corrosion of steel bars in slab will be started. From the field investigations, it was also found that corrosion of steel bars in slab was started earlier compared to the other structural members. Steel bars embedded in slab was corroded earlier than the steel bar embedded in other structural members due to the less cover as well as the use of lower quality concrete in slab compared to the other structural members.

The urban air pollution mostly from vehicle \& moto vehicle, industries/factories gases: like pulp \& paper, cement, mining, chemical \& pharmaceuticals, software and others emit gases like $\mathrm{CO}_{2}, \mathrm{SO}_{\mathrm{x}}, \mathrm{NO}_{\mathrm{x}}$ and $\mathrm{CO}$, are relevant parameters to the cause of corrosion to concrete reinforcements

\section{Case description}

Based on the literature survey, the research intended to evaluate the effect of the increased $\mathrm{CO}_{2}$ in Bangalore city and an on the spot test survey was conducted on 14 reinforced concrete structures. From the assessment, the amount of carbonation rate in Bangalore structures was found out.

\section{Methodology}

Visual inspection was first conducted before the detailed inspection for critical investigation. Detailed investigative study with both non-destructive tests (NDT) such as Rebound hammer test and ultrasonic pulse velocity test and Destructive testing techniques was employed were carried out on the reinforced concrete members in order to assess the surface hardness and strength of in-situ concrete as per the guidelines in Indian standard (IS:1311(Part11)-1992-(Reaffirmed in 2004). Half-cell Potential Measurements Test was carried out on RC members using Copper-Copper Sulphate. It was used to estimate the stage of corrosion in reinforcing bars using CANIN Corrosion analyzer as per the guidelines furnished by manufacturing's manual and ASTMTC-876-91 - (Reaffirmed in 1999). The cover meter studies were carried out on various RC members, in order to assess the thickness of cover concrete and to map the disposition of peripheral embedded rebar's in the RC members as per the guidelines of (ASTMTC-876- 91 - (Reaffirmed in 1999). Core test was conducted in order to assess the quality/ strength of in-situ concrete in RC members. The extracted core samples were subjected to compressive strength test after necessary trimming and capping as per the guidelines in IS: 516-1959 (Reaffirmed in 2013). Carbonation test was carried out on reinforced concrete members using phenolphthalein indicator in $0.1 \mathrm{~N}$ methyl alcohol to assess the extent of carbonation in cover of RC members. Chloride determination test was carried out on concrete to estimate the level of chloride in concrete. The permissible limit of quantity of chloride in concrete is $0.6 \mathrm{~kg} / \mathrm{m}^{3}$. Sulphates in concrete were determined by chemical analysis and expressed in terms of percentage of sulphate by weight of concrete. The permissible limit of quantity of sulphates in concrete is $0.4 \%$. The level of $\mathrm{pH}$ in fresh concrete is generally should be in the range of 12 to 14 . Due to carbonation, when $\mathrm{pH}$ of concrete falls below 10 , the alkalinity of the concrete will not be adequate to protect the rebars against corrosion. Results of this survey on fourteen structures and the tests conducted on samples are tabulated in Table 2 .

\section{Discussion of results}

This work was focused on corrosion of embedded steel in reinforced concrete structures and its possible causes in structures located in Bangalore. The evaluated structures were exposed to Bangalore moderate exposure condition. Hence nominal concrete cover was expected to be as stipulated by Indian standard code IS 456:2000 (Clause26.4.2). According to ASTM criteria for corrosion conditions, the corrosion potential of the rebars after reaching a quasi-stationary value lay between -0.420 and -0.380 VCSE. It is an indication of high risk of corrosion condition (90\% of risk) as per ASTMTC-876- 91(Reaffirmed in 1999) (Fig. 1).

This corrosion condition was found to be a more of general case for the almost the 14 structures evaluated. As per visual inspection, severe growth of vegetables \& fungus, damaged drainage system (leaking), dampness, cracks, Surface honeycombs, concrete cover spalling and exposed corroded rebar were common defects in almost fourteen structures surveyed. It was found that no maintenance had been done to these structures since when they were put in service as confirmed by the owners during the time of preliminary investigation. However, with examinations on foundation and tests on soil conducted, the safe bearing capacity of soil was 
satisfactory; no signs of settlement or disturbance to the foundation system were found of all structures considered.

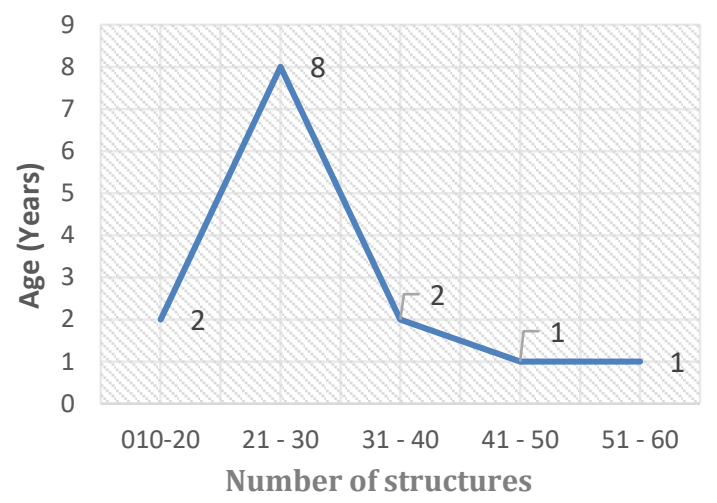

Fig. 1: Number of RC structures selected at random for evaluation and their range of age

As this is part of a continuous research on corrosion condition assessment in Bangalore. A combination of various NDT field techniques and laboratory investigations gives the basis for given conclusion. Since the overall foundation tests were satisfactory hence settlement has no effect on cracks commonly observed on members of structures surveyed. The concrete cover ranged between (1250 ) $\mathrm{mm}$, more than $67 \%$ of the structures surveyed had concrete cover thickness less than $30 \mathrm{~mm}$ and this is inadequate concrete cover to control the ingress of corrosive environment for long time (Monteiro et al., 2012).

More than $(80 \%)$ of structures surveyed were found with high probability of corrosion, with reference to Table 1 (Abaho et al, 2015). After the ingress of carbon dioxide, moisture and initiation of corrosion, corrosion rate was high as it depended on several factors like the aggressiveness of the surrounding environment lather the porosity concrete cover only.

With reference to the Table 1 (Abaho et al., 2015), it was observed that carbonation is the major cause of distress, being at steel level in all 14 structures evaluated. This is more confirmed by the $\mathrm{pH}$ lagging below 9 as shown in Table 2 and most of the structural members about $85 \%$ of inspected concrete structures. This means that steel reinforcement was no longer passivated hence prone to corrosion.

Table 2: Summary of the corrosion condition in concrete structures (Abaho et al., 2015)

\begin{tabular}{ccccc}
\hline S/N & Structures sample ID & Range of age (years) & Chloride Content range & pH Value range \\
\hline 1 & 13,6 & $10-20$ & $0.16-2.49$ & $8.34-11.6$ \\
2 & $14,12,10,9,8,1,3,4,5$ & $21-40$ & $0.4-0.79$ & $8.82-11.05$ \\
3 & 2,7 & $41-60$ & $0.34-0.54$ & $11.34-11.80$ \\
\hline
\end{tabular}

Fig. 1 shows the number of structures surveyed between (21-30) years of age. Variation of $\mathrm{pH}$ identified in structures was so huge and ranging from 8.34 to 11.8 , but average $\mathrm{pH}$ is below 10 as shown in Table 2. This was caused by the difference in structure exposure, difference in time of exposure (age) and non-uniformity of concrete cover.

With chemical tests analysis, it is observed that except 4 out of 14 structures (28.57\%), the quantity of chlorides in concrete was below limit to initiate corrosion (below chloride threshold) in 10 out of 14 $(71.43 \%)$ structures inspected. The permissible limit of quantity of chloride in concrete is $0.6 \mathrm{~kg} / \mathrm{m}^{3}$ as per the Indian Standard, IS: 456-2000 on the limit for chloride content in concrete. Therefore, it is not expected that reinforcement corrosion was due to chlorides. It can be observed that while carbonation was at the level of steel in all structures, chlorides seem not increase with the increase of concrete age unless concrete is defected with cracks or else if it is poor concrete and when the structures are located in chloride corrosive environment. It was that carbonation changed the total porosity and a redistribution of pore sizes and there limiting the chloride ion diffusion and concentration was low as was identified with the chemical analysis on the cores extracted from these investigated structures. The chloride binding capacity is decreased with carbonation due to change in cement gel in relatively coarse crystalline products and the decrease in $\mathrm{pH}$ of pore solution (Table 3).

Table 3: Estimated coefficient of carbonation of different structural members

\begin{tabular}{cc} 
Table 3: Estimated coefficient of carbonation of different structural members \\
\hline Structural element & Average coefficient of carbonation $-\mathrm{K}\left(\mathrm{mm} /\right.$ year $\left.^{0.5}\right)$ \\
\hline Slab & 4.420 \\
Beam & 3.510 \\
Column & 3.905 \\
Others & 3.475 \\
Average & 3.8275 \\
\hline
\end{tabular}

Carbonation measurements were taken from different structural members, such as, slab, beam, column, stair, sun shade, shear wall, etc. footings, Stair case, sun shade, and shear wall categorized as other structural member as shown in Fig. 2 as well as Table 3.

A total of 80 samples from fourteen different structural members were considered as shown in
Fig. 3. On top of other factors pointed out, high temperature of around $2.5^{\circ} \mathrm{C}$ (Ramachandra and Kumar, 2010) has simultaneous effect on different parameters which might counter balance each other. The oxygen content as well as $\mathrm{pH}$ value of pore solution decrease and the concentration of chloride ion increases when temperature rises. 


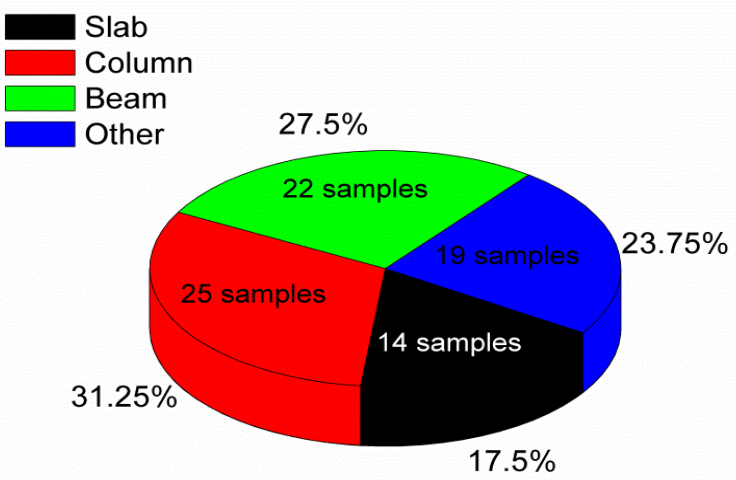

Fig. 2: Structural member samples tested for carbonation

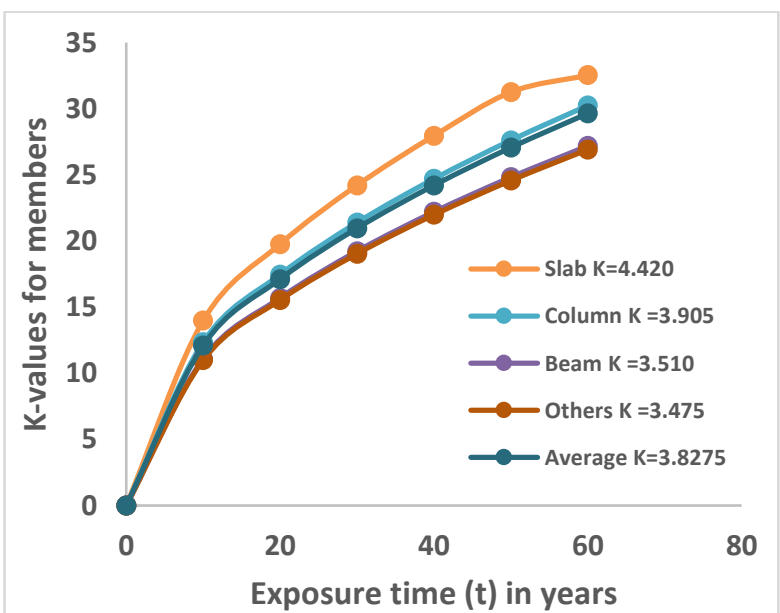

Fig. 3: Carbonation depth in concrete against structure exposure time

With good concrete carbonation coefficient should range between (0.25-1) mm/year-1/2 (Broomfield, 1997; Tuutti, 1982). Also it was found that with good quality concrete, concrete cover 30 $\mathrm{mm}$ was sufficient at design level of 60 years' structures design service life for carbonation penetration control while the carbonation coefficient was estimated to be $3.76 \mathrm{~mm} /$ year 0.5 .

In the present study, the analysis of quality concrete cover in structures surveyed was done with the use of formula mentioned in Eq. 4 and the resultant carbonation coefficient curves were as in Fig. 3. The average carbonation coefficient in the structures surveyed is found to be $3.83 \mathrm{~mm} /$ year $^{\mathbf{0 . 5}}$. This is $0.07 \mathrm{~mm} /$ year $^{0.5}$ higher compared to carbonation coefficient of $3.76 \mathrm{~mm} /$ year 0.5 (Monteiro et al., 2012), In Fig. 4 the difference of carbonation coefficient in surveyed structures from Monteiro findings with the present study was due to poor quality of concrete to control the rate of carbonation but also it is an indication of high carbon dioxide concentration in the atmospheric environment in question. However, it was to be a small or different but should not miss lead the interpretation since it was an average of carbonation coefficient, a small deviation means a big difference. It was found that slabs had more average carbonation coefficient $\mathrm{K}$ (mm/year ${ }^{0.5}$ ) of 4.42 compared to 3.91, 3.51 and 3.46 for columns, beams and others respectively as indicated in Table 3 . It was observed that carbonation depth increased with the time, the atmospheric air exposure with age (environmental exposure class XC3).

In structures (6 and 14), it was found that chlorides also sulphates contents in concrete were beyond the permissible limit of $0.6 \mathrm{~kg} / \mathrm{m}^{3}$, corrosion of steel reinforcement and carbonation had reached the level of steel as well.

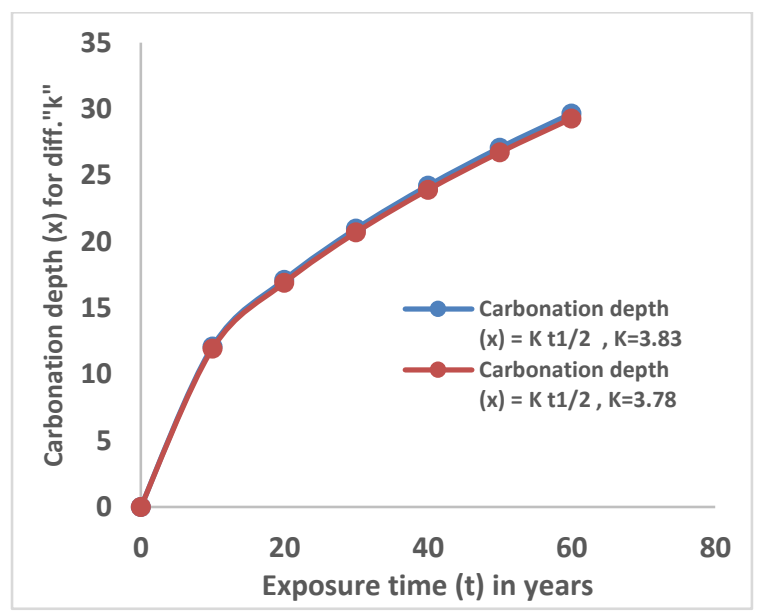

Fig. 4: comparison of the findings between the present researches with (Monteiro et al., 2012) about carbonation coefficient

In such a situation, it is not easy to specify the major cause of corrosion of steel in concrete since the influence of each parameter is not specific, a combination and a resultant effect due to their interactions is apparent. However, the rate of steel corrosion in concrete structures affected by chloride ion penetration is much faster than in carbonationinduced corrosion (Branco and Brito, 2004).

With reference to the Table 4 , the concrete cover to be used in Bangalore is $30 \mathrm{~mm}$ since it has moderate exposure condition as per the corrosion map of India.

Table 4: Nomial concrete cover as per IS 456:2000 (Clause

\begin{tabular}{cc} 
& $26.4 .2)$ \\
\hline Exposure condition & $\begin{array}{c}\text { Nominal concrete cover not less } \\
\text { than }(\mathrm{mm})\end{array}$ \\
\hline Mild & 20 \\
Moderate & 30 \\
Severe & 45 \\
Very severe & 50 \\
Extreme & 75 \\
\hline
\end{tabular}

Irrespective of the exposure conditions and structural elements, the average carbonation coefficient is found to be $3.83 \mathrm{~mm} /$ year $^{0.5}$ as shown in Table 3 .

Carbonation coefficients of various structural elements are summarized in Table 3 for various exposure conditions. A higher value of carbonation coefficient is found to be caused by poor quality concrete, low concrete cover as compared to durability requirement with reference to the Table 4 as well as moderate carbonation environment in Bangalore city. 


\section{Conclusion}

Reinforced concrete structures perform well when the alkaline environment is intact (Neville, 1995). That is, when the level of $\mathrm{pH}$ in concrete keeps in the range of 12 to 14 . At this level of $\mathrm{pH}$, the reinforcement bar is protected from corrosion condition by a thin passive layer which is normally sprayed over the reinforcement bar. However, the $\mathrm{pH}$ was found to averagely range below 10 in surveyed structure in this particular study. It was found that some structures had inadequate cover over the reinforcement. According to Indian standards (IS 456:2000), the concrete cover to be used in Bangalore is $30 \mathrm{~mm}$ since the structures are exposed to moderate exposure condition. This is in agreement with the findings that for 60-years designed service life structure in moderate environment shall have at least $30 \mathrm{~mm}$ concrete cover to protect steel reinforcement from early corrosion initiation (Monteiro et al., 2012). According to Monteiro model, the average carbonation coefficient in good concrete exposed to moderate environment should be $3.73 \mathrm{~mm}$ /year0.5 in good concrete. When carbonation coefficient goes above this (as the present finding), it implies a need for alteration in normal concrete cover, especially by increasing concrete cover depth, reduce concrete permeability by reducing its porosity.

Based on the findings indicated above, the norms and standards, it can be concluded that the structures surveyed were suffering from carbonation induced corrosion. The average carbonation coefficient of $3.83 \mathrm{~mm} /$ year $^{0.5}$ found in structures at Bangalore city, was comparably high. The carbonation front, hence, the carbonation induced corrosion can be minimized by increasing concrete cover to a thickness greater than $30 \mathrm{~mm}(35 \mathrm{~mm}$ $40 \mathrm{~mm}$ ), improving the quality of concrete by reducing its porosity, and limiting the carbon dioxide source that cause carbon dioxide gas at Bangalore atmosphere. Also, timely maintenance was found to be a relevant and important solution for carbonation induced corrosion minimization.

\section{References}

Abaho GG, Pranesh MR, Sudarshan SI, and Senthil KG (2015). A comparative study on causes of corrosion of steel reinforcement in RC structures at Bangalore, India and Kigali, Rwanda. International Journal of Engineering and Technology (IJET), 7(3): 1041-1048.

ACI (1992). Building code requirements for reinforced concretes. American Concrete Institute (ACI 318-89), Detroit, USA.
Ahmad Z (2006). Principles of corrosion engineering and corrosion control. Elsevier Science \& Technology Book, London, UK.

Al-Kadhimi TKH, Banfill PFG, Millard SG, and Bungey J H (1996). An accelerated carbonation procedure for studies on concrete. Advances in Cement Research, 8(30): 47-59.

Bentur A, Diamond S, and Berke N (1997). Steel corrosion in concrete, fundamental and civil engineering practice. E \& FN Spoon, London, UK.

Berke NS and Hicks MC (1994). Predicting chloride profiles in concrete. Corrosion, 50(3): 234-239.

Branco FA and Brito JDe (2004). Handbook of concrete bridge management. American Society of Civil Engineers, Reston, USA.

Broomfield JP (1997). Corrosion of steel in concrete understanding, investigation and repair. E \& FN Spoon, London, UK.

Fu X and Chung D (1997). Effect of corrosion on the bond between concrete and steel rebars. Journal of Cement Concrete Research, 27(12): 1811-1815.

Gajanan MS (2012). Green building with Concrete-Sustainable design and construction. CRC press, New York, USA.

Guha T and Ghosh P (2015). Diurnal and seasonal variation of mixing ratio and $\delta 13 \mathrm{C}$ of air $\mathrm{CO} 2$ observed at an urban station Bangalore, India. Environmental Science and Pollution Research, 22(3): 1877-1890.

Ho DWS and Lewis RK (1987). Carbonation of concrete and its prediction. Cement and Concrete Research, 17(3): 489-504.

Maslehuddin M, Page CL, Rasheeduzzafar CL, and Al-Mana AI (1996). Effect of temperature on pore solution chemistry and reinforcement corrosion in contaminated concrete. In: Page CL, Bamforth PB, and Figg JW (Eds.), Corrosion of reinforcement in concrete construction: 67-75. Special Publication-Royal Society of Chemistry, Cambridge, UK.

Monteiro I, Branco FA, De Brito J, and Neves R (2012). Statistical analysis of the carbonation coefficient in open air concrete structures. Construction and Building Materials, 29: 263-269.

Neville AM (1995). Properties of concrete. $4^{\text {th }}$ Edition, Longman Group Limited, Harlow, UK.

Neville AM (2004). Properties of concrete, $4^{\text {th }}$ Edition, Pearson Education Limited, UK.

Ramachandra TV and Kumar U (2010). Greater Bangalore: Emerging urban heat island. GIS Development, 14(1): 86-104.

Saetta AV, Schrefler BA, and Vitaliani RV (1993). The carbonation of concrete and the mechanism of moisture, heat and carbon dioxide flow through porous materials. Cement and Concrete Research, 23(4): 761-772.

Schiessl P (1998). Corrosion of steel in concrete. Report of the Technical Committee 60 CSC RILEM, Chapman and Hall, London, UK.

Sudhira HS, Ramachandra TV and Balasubrahmanya MH (2007). City profile Bangalore. Cities, 24(5): 379-390.

Tuutti K (1982). Corrosion of steel in concrete. Swedish Cement and Concrete Research Institute. Stockholm, Sweden. 